\title{
The effect of environmental change on Early Aptian Ostracoda in the Wessex Basin, Southern England
}

Ian P. Wilkinson

British Geological Survey, Keyworth Notts. NG12 5GG, UK

A major phase of transgression in the Wessex Basin (southern England) during the earliest Aptian resulted in the collapse of the generally fresh water Barremian environment and the initiation of the marine mileu.

Cypridea-rich faunas low in the Shepherd's Chine Member (Vectis Formation), were gradually replaced by faunas dominated by Sternbergella cornigera, Mantelliana mantelli and Theriosynoecum fittoni. This change is interpreted as indicating that salinities had passed from fresh-oligohaline to meso- and pliohaline and that ephemoral water bodies were replaced by more widespread, permanent, lagoonal waters. The ostracods from the highest part of the Vectis Formation, appear to be heralding the major transgression that was about to engulf the Wessex Basin.

The marine incursion during the obsoletum Subzone brought with it newly formed environmental niches that were rapidly occupied by microfaunas. Several ostracod species are euryhaline, but others appear to have been restricted to marine or near marine salinities. The earliest marine ostracod faunas were recorded from the Perna Bed Member, Isle of Wight, and include abundant Asciocythere albae and frequent to common Schuleridea derooi, Neocythgere gottisi, N. bordeti and Cytherelloidea sp. Other species include rare Cythereis geometrica, C. semiaperta, Cytheropteron stchepinskyi and Protocythere croutesensis. In addition, elsewhere in southern England, Protocythere mertensi langi, Dolocytheridea intermedia, Paranotacythere (P.) oertlii and P. (P.) atypica occur. The relationship of this earliest Aptian population with that of the Paris Basin cannot be mistaken.

Key words: Ostracoda, Aptian, Wessex Basin, palaeoenvironmental change. 


\section{Introduction}

The earliest Aptian was a time of major change in the Wessex Basin with marine conditions returning for the first time since the end of the Jurassic. Flooding of the low-lying, topographically subdued areas in which the Wealden Clay and Vectis formations had accumulated, was geologically instantaneous. The abrupt palaeoenvironmental change profoundly affected the ostracod community of the Wessex Basin- in broad terms the fresh water faunas of the late Barremian were replaced by marine taxa by the early Aptian.

The Cypridea-rich associations of southern England have been described in detail by Anderson in several classic papers (1985 and references therein) and his concepts were later discussed by Horne (1995). Previous work on the earliest marine Aptian ostracod faunas of southern England has concentrated on taxonomy (Kaye, 1965), but their relationship to the stratigraphy and palaeoecology has not been considered in any detail (Wilkinson, 1996). The aim of the present work is to examine the earliest Aptian ostracod faunas of the Wessex Basin in detail, in order to determine how these major palaeoenvironmental changes affected their migration into the region. In order to do this, successions from the Isle of Wight and boreholes in Sussex and Surrey (Fig. 1) are considered.

\section{Stratigraphy}

\subsection{Vectis and Weald Clay formations}

The Shepherd's Chine Member at the top of the Vectis Formation has traditionally been placed into the Upper Barremian. However, it is at least in part younger than the earliest Aptian magnetostratigraphic chron CM-0 (suggesting a position within the bodei Subzone fissicostatus ammonite Zone) (Fig. 2). The overlying Perna Beds have a fissicostatus Zone, obsoletus Subzone macrofauna, so that, unlike eastern England, the earliest macrofossil subzone in the Vectis Basin (bodei Subzone) is represented by non-marine facies. Thus, the stratigraphical gap between the Vectis Formation and overlying Atherfield Bone Bed, at the base of the Perna Beds, represents a very short period of time. 
The Vectis Formation of the Isle of Wight (Text figure 2), which comprises mainly dark grey mudstones, is divided into three members, but only the highest of these, the Sheperd's Chine Member, is considered here. This member consists of rhythmic grey, fine-grained sands and silts passing up into dark grey clay in about 65 thin, upwardly fining units (Insole et al., 1998). The base of each unit is generally erosional. Towards the top of the member, thin, shelly, argillaceous limestones occur containing the bivalve Filosina and, near the top, Ostrea.

The Formation correlates, in part, with the uppermost part of the Weald Clay Formation in the Wealden Province of Surrey, Sussex and Kent (Text figure 2). The formation is rarely exposed in this region, although it was formerly recorded in a few brick pits, where it was composed of grey and brown clays, locally shaley or silty, with beds of 'Paludina' limestone and occasional ironstone (e.g. Thurrell et al., 1968; Young \& Lake, 1988; Insole et al., 1998).

\subsection{Atherfield Clay Formation}

The Perna Member, which accumulated in a shallow marine environment, was named after the bivalve Mulletia mulleti, formerly Perna mulleti, which occurs in large numbers. The unit comprises a basal grit (the Atherfield Bone Bed of Simpson, 1985), a transgressive lag consisting of small pebbles, phosphatic nodules (some containing Kimmeridgian ammonites) and fish and reptile debris (Simpson, 1985, Hart et al., 1991). Overlying the bone bed are dark greenish-grey, fine-grained clayey sand and sandy clay, containing bivalves, echinoids, brachiopods as well as the earliest microfaunas, including rare, generally agglutinated foraminifera and very rare dinoflagellate cysts (Hart et al., 1991). Shelly, microfossils have not been recorded from the more indurated, glauconite-rich, highly bioturbated medium- to coarse grained, calcareous sandstone of the Upper Perna Bed. Casey (1961) placed the Perna Beds Member in the Prodeshayesites obsoletus Subzone, although hinted that, although evidence is lacking, the Atherfield Bone Bed might be of Prodeshayesites bosei subzonal age.

The Chale Clay Member (formerly called the Atherfield Clay) (Simpson, 1985) comprises up to $21 \mathrm{~m}$ of brown-weathering, dark grey, silty clay, with red nodules in the lower part. On sedimentological grounds the unit accumulated in shallow marine conditions with storm events resulting in silty lags (Insole et al., 
1998). Although poorly fossiliferous, bivalves occur and the ammonites place the unit within the Deshayesites fittoni Subzone.

The remainder of the Atherfield Clay Formation (Fig. 2) comprises brown-grey mudstones and fine sands which show upward coarsening in some parts. Scattered phosphatic and calcareous concretions are present and occasional wave ripples and scoured surfaces occur. Between Chale Bay and Atherfield Point, Isle of Wight, this part of the formation can be divided into three units, which have variously been called 'divisions', 'beds' or 'members' (e.g. Fitton, 1847; Casey, 1961; Simpson, 1985; Insole et al., 1998): Upper Lobster Bed (at the top), Crackers Bed and Lower Lobster Beds (at the base). These subdivisions are geographically very restricted; they rapidly become more uniform, so that, for example, the Crackers Beds is represented only by a sandstone interval at Red Cliff (Simpson, 1985) and offshore in BGS Borehole 75/35 (Dingwall \& Lott, 1979; herein).

In Surrey, the Atherfield Clay comprises "15-60 feet [4.6-18.3 m] of brown and grey sandy clay and buff loam with concretions of clay ironstone or calcareous stone at the base (Perna Beds)" (Casey, 1961). It is rarely exposed, but in the past brick pits have yielded the characteristic macrofaunas seen in the Isle of Wight. In Sussex, the Atherfield Clay Formation comprises brown and grey silty clays up to approximately $18 \mathrm{~m}$ thick, although, again, it is very rarely exposed and the Perna Member has not been observed.

\section{Ostracods in the Wessex Basin}

\subsection{Isle of Wight}

Atherfield Bay (Fig. 3). Anderson (1971) lised the ostracods from the upper 40m of the Shepherd's Chine Member. Species of Cypridea, such as C. cuckmerensis and C fasciata commonly occurred and, although less common, non-Cypridea taxa such as Sternbergella cornigera and Mantelliana mantelli were present. However, at the top of the section (about $6 \mathrm{~m}$ below the Perna Beds), Cypridea is less dominant, replaced by more numerous "S-phase" species. Cypridea was found in a sample $3 \mathrm{~m}$ below the top of the Shepherd Chine Member in the Atherfield-Shepherd's Chine area, but the fauna recovered from $0.3 \mathrm{~m}$ below the base of the Perna Member is dominated by the 'S-phase' species Sternbergella cornigera, and Mantelliana mantell; species of Cypridea had disappeared from the record. 
Sandown Bay (Fig. 4). Stewart et al. (1991) indicated that C-phase ostracods are not found in the highest part of the Vectis Formation (highest Shepherds Chine Member), the fauna being entirely S-phase, although no details were given. The present author examined a sample from the highest Vectis Formation at Sandown Bay, 0.25m below the contact with the Atherfield Bone Bed, where only very rare specimens of Sternbergella cornigera were found.

The earliest marine ostracod faunas to enter the Wessex Basin were recorded from the lower Perna Bed, which were examined at Sandown Bay, Isle of Wight (Figure 4). The more successful species include abundant Asciocythere albae and frequent to common Asciocythere sp, Schuleridea derooi, Schuleridea sp, Neocythere gottisi, $N$. bordeti and Cytherelloidea sp. Other species include rare Cythereis geometrica, $C$. semiaperta, Cytheropteron stchepinskyi and Protocythere croutesensis. There is little difference in the faunas throughout the Lower Perna Bed, except Cythereis tends to become more common up sequence at the expense of Neocythere and Cytherelloidea.

BGS Borehole 75/35 (Fig. 5) A sparse fauna, was recovered in a borehole (British Geological Survey borehole 75/35) to the east of Sandowm, Isle of Wight (Latitude $50^{\circ} 37.81^{\prime} \mathrm{N}$ Longitude $\left.1^{\circ} 5.54^{\prime} \mathrm{W}\right)$. Here the Atherfield Clay Formation comprised upwardly coarsening rhythms which can be related to the Atherfield succession only with difficulty (Dingwall \& Lott, 1979).

Upper Lobster Bed. Olive-brown, silty, micaceous clay with ammonites (21.6m thick)

?Crackers Bed. brown-grey, silty, shelly clay, overlain by brown-grey, silty, finegrained sandstone $(5.75 \mathrm{~m}$ thick)

?Lower Lobster Bed. Grey, micaceous siltstone with day lenses, overlain by grey, silty sandstone $(9.60 \mathrm{~m}$ thick)

Chale Clay Member:

Brown-grey, fossiliferous mudstone with occasional calcareous and phosphatic nodules. $\quad 29.35 \mathrm{~m}$ (base not seen).

Kaye (1965) described a fauna comprising 19 species from the Chale Bay Member (D. forbesi Zone, D. fittoni Subzone), onshore, although he gave little stratigraphical and geographical information. In borehole 75/35, ostracods were less diverse (TextFig. 5), however, it is characterised by Schuleridea derooi, S. sulcata, Neocythere 
(Centrocythere) bordeti and Cythereis geometrica together with occasional Asciocythere alba, and Dolocytheridea intermedia at the base and Paranotacythere inversa tuberculata and Protocythere mertensi langtonensis in the upper part.

Kaye (1965) mentioned only Schuleridea sulcata from the Upper Lobster Member and no species at all from the Lower Lobster Member. Unfortunately samples from the higher part of the Atherfield Clay in borehole 75/35, were almost barren of ostracods, although rare agglutinated foraminifera and 'lignite' chips were present. The only ostracods recovered were from the Crackers Bed, which contained very rare Cythereis geometrica and Veeniacythereis cf blanda, and a specimen of $C$. geometrica from the upper part of the Upper lobster Bed.

\subsection{West Sussex}

Unlike the Isle of Wight, moderately diverse associations were encountered in the upper part of the Atherfield Clay Formation of Paylins Copse Borehole (National Grid Reference SU8691 2383), Pound Common Borehole (SU8756 2471) and Frog Farm Borehole (SU9725 2048), West Sussex (Figs. 6, 7 and 8 respectively). The lower and middle parts of the formation yielded Dolocytheridea intermedia, Neocythere $(C$.) bordeti, Schuleridea sulcata and Protocythere derooi, with less common Paracypris sp., Dolocythere rara, Cythereis sp. and Cytherella cf. ovata. Towards the top of the formation, Neocythere $(C$.) gottis, Veeniacythereis cf. blanda, Cythereis cf. buechlerae and Schuleridea sp characterise the assemblage.

The Hoes Farm Borehole (National Grid Reference SU 9808 1962) penetrated through the Sandgate and Hythe formations before terminating in the Atherfield Clay Formation (Bristow et al., 1987). The last named formation can be placed within the D. callidiscus Subzone and is, therefore, equivalent to the Upper Lobster Bed and Crackers members of the Isle of Wight succession. The fauna is almost identical to the lower part of the forbesi Zone. The most common species found here (Fig. 9) were Dolocytheridea intermedia, Neocythere (C.) bordeti and Schuleridea sulcata, although none of the faunas contained abundant ostracods, but Protocythere croutesensis and $P$. mertensi langtonensis were occasionaly present.

There is a change in the fauna in the basal part of the Hythe Formation (D. deshayesi Zone, $C$. parinodum Subzone) with the appearance of species such as Neocythere $(C$.) 
gottisi, Platycythereis cf. rectangularis, Cythereis geometrica geometrica and Veeniacythereis cf. blanda.

\section{Biostratigraphy}

The Aptian succession of southern England can be subdivided into two zones and four subzones (Fig. 2) based on the distribution of ammonites (Casey, 1961). The bodei Subzone at the base of the fissicostis Zone cannot be recognised in the Wessex Basin because salinity during the accumulation of the Shepherd's Chine Member was too low (the subzone was defined in East Anglia). It is shown here to include that part of the Aptian below the first ammonite-bearing strata and above the magnetostratigraphic chron CM-0.

Previous studies of the marine ostracods have concentrated on the systematic palaeontology, rather than biostratigraphy. The Shepherd's Chine Member can be assigned to Assemblage 15 (of Anderson, 1985) and the Theriosynoecum fittoni Zone (of Horne, 1995). No attempt has been made to subdivide the Atherfield Clay by means of ostracods, however, there is sufficient evidence to suggest the presence of:

a lower zone defined by the appearance of Neocythere gottisi with Cythereis semiaperta, Cytheroptern stchepinskyi and Schuleridea derooi. It is equivalent with the $P$. obsoletus and $D$. fittoni subzones of the standard macrofaunal scheme.

an upper zone in which Schuleridea sulcata becomes the more characteristic species, accompanied by long-ranging taxa, but lacking Cythereis semiaperta, Cytheroptern stchepinskyi and Schuleridea derooi. Neocythere bordeti tends to replace $N$. gottisi. The Zone is equivalent to the D. kiliana and D. callidiscus standard macrofaunal subzones. Its top is placed at the incoming of Platycythereis rectangularis and Asciocythere albae rectilinea at the base of the Ferruginous Sands/Hythe formations (the Deshayesites deshayesi standard macrofaunal Zone).

\section{Migration}

With the opening of the sea way at the beginning of the Aptian, three basins became interconnected, allowing migration between: the Wesex Basin, the Celtic Sea Basin in the west and the Paris Basin to the south-east. 
A diverse ostracod population has been recovered from the Aptian of the Celtic Sea, dominated by Bairdoppilata and Cytherella (Colin et al., 1981; Ainsworth, 1985, 1986, 1987; Ainsworth et al., 1985, 1987). Few species appear to have migrated from the Celtic Sea Basin into the Wessex Basin, implying that a physical or biological barrier seperated the two. It is interesting to note that, only five species are common to both the Celtic and Wessex Basin (although several others show close affinities), despite their close proximity. One example, is a single fragment of Quasihermanites sp cf bicarinata is similar to that figured by Hart \& Crittenden(1985) (as Eucythere ornata) from the latest Barremian of the Goban Spur. Of those present in the two basin, several appear to have originated in the Paris Basin and taken the opportunity to migrate widely. Neocythere (Centrocythere) bordeti and $N .(C$.) gottisi, for example, appear to have migrated from the Paris Basin into both the Wessex and Celtic Basins during the early Aptian.

Only early Aptian (D. deshayesi Zone) ostracods have been recognised in the Paris Basin (Deroo, 1956; Damotte \& Grosdidier, 1963; Damotte, 1971; Damotte \& Magniez-Jannin, 1973; Babinot et al., 1985). Neocythere (Centrocythere) bordeti and Eocytheropteron stchepinskyi continue through from the highest Barremian, but a number of species appear for the first time in the Aptian, including Cythereis (Rehacythereis) geometrica, Neocythere (Centrocythere) gottisi, Protocythere croutesensis, Asciocythere albae and Schuleridea derooi. Cythereis lamplughi was recorded in the upper part of the D. deshayesi Zone in the Paris Basin (Babinot et al., 1985). Ostracods in the earliest Aptian deposits of the Wessex Basin bear a close resemblance to faunas of the Paris Basin. Asciocythere albae albae, is particulary comon in both the Wessex and Paris basins and appears to have been a succesful opportunist. Others, such as Eocytheropteron stchepinskyi, Protocythere croutesensis and Cythereis (Rehacythereis) geometrica, are not common in southern England, although the last named species ranges up into the bowerbanki Zone (transitoria Subzone) in Sussex.

Sauvagnat (1999) ajnd Sauvagnat et al. (2001) showed that further south-east, in the Bedoulian of the Jura and Alps, Asciocythere, Schuleridea, Paracypris, Protocythere and Cythereis are particularlt diverse. Several species recovered here have a wide geographical distribution; e.g. Neocythere $(C$.) gottisi, Protocythere croutesensis, Eocytheropteron stchepinskyi and Schuleridea cf derooi. Protocythere and Cythereis 
are biostratigraphically useful in the Mesogean region of France (Babinot et al., 1985 and references therein). Very rare specimens tentatively assigned to Bedoulian taxa have been found in the Wessex Basin: "Protocythere" sp 3 and Cythereis buchlerae, for example, were originaly found in the Aptian of Mesogean France (Oertli, 1958; Babinot et al., 1985). Strigocythere? reticulata (“Cythereis" sp 307 of Oertli, 1958), was first described from the Gargasian of Apt, but has since been described from elsewhere in south-eastern France (Sauvagnat, 1999; Sauvagnat et al., 2001) and as far north as the Celtic Basin (Colin et al., 1981).

It seems clear, therefore, that despite the fact that a few species may have been derived from the west, by far the largest number of species in the Wessex Basin originated in the Paris Basin, perhaps having migrated there from yet further south east. Geologically rapid migration took place with the opening of the early Aptian seaway.

Despite the sudden transgression into the Wessex Basin, reworked species are rare. The thin shelled, fresh water taxa of the Wealden Clay are probably too fragile to be transported far. However, a single, quartz encrusted valve of Macrodentina (Polydentina) cf steghausi found in the Perna Member of Sandown, appears to have been reworked from the lower Kimmeridge Clay Formation.

\section{Palaeoenvironments}

Earliest Aptian ostracod faunas have been recorded from the East Midlands Shelf of eastern England, where conditions limited the assembalges to a few species capable of tolerating kenoxia, such as Acrocythere hauteriviana, Apatocythere ellipsoidea, Pontocyprella rara and Schuleridea hammi (Wilkinson, 1996). In the southern North Sea Basin, diversity was much higher (Lott et al., 1985) in the better oxygenated waters. Here, a number of taxa that had first appeared in the Barremian extended through to the early Aptian, including Veeniacythereis acuticostata, Cytheropteron reightonensis, Infracytheropteron exquisita, Paranotacythere inversa tuberculata and Cardobairdia minuta. They occur together with more typical Aptian forms such as Protocythere intermedia, Paracytheridea minutissima and Paracypris acuta. However, faunas of the Wessex Basin show many differences due to the palaeogeography at that time. It was only with the opening of the Bedfordshire 
Straights during the mid and late Aptian that ostracod faunas in the two basins began to mix.

\section{P. fissicostis Zone}

The Shepherd's Chine Member is interpreted as a shallow, storm influenced lagoon deposit (Stewart, et al 1991), on the basis of sedimentary structures. Its cyclicity reflects intermittent increases in the fluvial input and flooding events into the lagoon, and it has been suggested that these may be climatically controlled (Insole, Daley and Gale, 1998). Ruffell (1988) and Radley (1995) argued that the faunas indicate an upward increase in salinity.

The typical uppermost Wealden Clay/Vectis Formation ostracod assemblages, are dominated by Theriosynoecum fittoni, together with less common Mantelliana mantelli, Sternbergella cornigera, Darwinula leguminella, and rare Cypridea spinigera, C. fasciata, C. tenuis etc. In the sense of Anderson (1985, and references therein), the S-phase element dominates over the C-phase, but it is not clear how much of this is a reflection of salinity (Anderson's favoured explanation), and how much other parameters such as water chemistry, permanency of the water body, climatic fluctuations, etc.

Cypridea was restricted to fresh-water and oligohaline conditions ( $<3$ mille) at this time, but it also had dessication resistant eggs and was therefore able to colonise ephemeral waters (Whatley, 1990). Theriosynoecum and Darwinula apparently preferred oligo- and mio- haline conditions (Fig. 10), and although they tolerated salinities up to the lower part of the mesohaline range, they colonised only permanent water bodies. Mantelliana was euryhaline, although probably colonised areas only when miohaline salinities had been reached. Sternbergella cornigera probably had similar environmental requirements.

At the end of the Barremian and the beginning of the Aptian, ostracod assemblages varied according to the local environmental conditions. For example, in Surrey, Cypridea is found together with Theriosynoecum fittoni in the upper part of the Weald Clay (Butler, 1922), but in the highest part, within a few metres of the Perna Bed, only T. fittoni was recorded. On the northern margin of the Wessex Basin, in the Warlingham Borhole, Theriosynoecum fittoni comprises $90 \%$ of the uppermost $7 \mathrm{~m}$ of the Weald Clay Formation and within the topmost $1.5 \mathrm{~m}$ foraminifera also appear 
(Anderson 1971). This would suggest that salinities had passed from fresholigohaline to meso- and pliohaline. On the other hand, Anderson (1967, 1985) indicated that Cypridea is present, although scarce, in the highest part of the Weald Clay, in Warlingham Borehole and Atherfield, possibly derived from nearby localities where fresh and oligohaline conditions continued.

There is also a suggestion that the introduction of non-Cypridea faunas occurred when ephemoral water bodies were replaced by more widespread, permanent, lagoonal waters. The ostracods from the highest part of the Vectis Formation, therefore appear to be heralding the major transgression that was about to engulf the Wessex Basin.

\section{P. fissicostis Zone, P. obsoletus Subzone}

The Atherfield Bone Bed at the base of the Perna Member (Simpson, 1985), represents a transgressive lag. The remainder of the Perna Member contains evidence of shallow, oligohaline to miohaline conditions, probably associated with the lagoonal and interdistributary bays (Kerth \& Hailwood, 1988; Stewart et al., 1991; Hart et al., 1991). The marine incursion into the region took place during the obsoletum Subzone, and brought with it both macro and micro faunas which rapidly occupied the newly formed environmental niches. The typical Wealden assemblages were replaced by associations employing new strategies.

The relationship of the earliest Aptian population Sandown Bay, Isle of Wight with that of the Paris Basin (Damotte \& Grosdider, 1963; Damotte \& Magniez-Janin, 1973; Babinot et al., 1985) cannot be mistaken. There are some similarities with the latest Barremian to early Aptian faunas of the Fastnet Basin and Celtic Sea (Ainsworth, 1985, 1986, 1987; Ainsworth et al., 1985, 1987), although Cytherella is more abundant, probably due to greater kenoxia. There appears to be little in common with south-eastern France, with the possible exception of a single specimen of a species very closely related to Protocythere sp.3 (Babinot et al., 1985) from the Bédoulien of Ardèche. This shallow, near-shore, warm water fauna must have entered the Wessex Basin via the Paris Basin, very quickly after the opening of the marine connection during the earliest Aptian, when salinities had edged towards the upper part of the brachyhaline range and fully marine.

\section{D. forbesi Zone, D. fittoni Subzone}


The Chale Bay Member accumulated in a shallow marine environment which suffered occasional storm events that resulted in the formation of thin silty lags. Ostracods include Neocythere (N.) gottisi, Neocythere (C.) bordeti, Protocythere croutesensis, Cythereis geometrica, Eocytheropteron stchepinskyi, Schuleridea derooi, Dolocytheridea cf. intermedia and a number of species of Paranotacythere including P. (P.) oertlii and P. atypica. The assemblage is similar to the faunas recovered from the Perna Bed, although Paranotacythere is more numerous.

Of those taxa found in the Chale Bay Member, Schuleridea is a euryhaline genus that apparently tolerated Pliohaline to fully marine salinities and Dolocytheridea could tolerate reduced salinities down to the higher part of the brachyhaline salinity range (Fig. 10). The remaining species, however, are restricted to fully or near marine salinities. Paranotacythere (P.) oertlii and Protocythere mertensi langtonensis, which appear towards the upper part of the member, are restricted to the shallow marine milieu.

\section{D. forbesi Zone, D. kiliana Subzone}

According to Insole et al (1998), in the Isle of Wight, the upper part of the Atherfield Formation accumulated in shallow, and gradual shallowing, marine conditions, resulting in a general up-section coarsening through the Lower Lobster Bed and an increase in the presence of storm generated deposits. Ostracods are extremely rare in the upper part of the Atherfield Clay Formation around Atherfield, Isle of Wight, and their provenance is uncertain.

\section{D. forbesi Zone, D. callidiscus Subzone}

Heselbo, Coe \& Jenkyns. (1990) considered that the 111 Ma maximum flooding surface (of Haq et al., 1987) could be placed at the Crackers Bed (callidiscus Subzone). The Crackers Bed shows a number of breaks in sedimentation resulting in ommission surfaces with scour, fluid escape and slump structures and current alligned macrofossils testifying to the very shallow water environment. The Upper Lobster Beds shows a return of environmental conditions similar to those for the Lower Lobster Bed.

Ostracods are rare in the upper part of the Atherfield Clay Formation of the Isle of Wight: Kaye (1965) mentioned only Schuleridea sulcata from the Upper Lobster Member of Atherfield and Cythereis geometrica and Veeniacythereis sp cf V. blanda 
occur in the Crackers in borehole 75/35. In Sussex, however, ostracods in the $D$. callidiscus Subzone are essentially similar to that of the Chale Bay Member. Species such as Schuleridea sulcata are euryhaine (pliohaline to euhaline), while Dolocytheridea intermedia can tolerate salinities as low as mid brachyhaline. However, the majority (e.g. species of Protocythere, Cythereis, Paranotacythere and Asciocythere) are near marine (upper brachyhaline) to marine (euhaline) taxa.

\section{Conclusions}

The distribution of Aptian Ostracoda in the shallow water deposits of Britain is dependant on both local and regional factors related to palaeogeography, facies, salinity, temperature, etc.

In the Wessex Basin, the earliest Aptian was a period of rapid transgression, during which time ostracod populations characteristic of oligohaline and miohaline conditions were replaced by brachyhaline and fully marine faunas. Species of genera such as Cypridea were replaced by Mantelliana and by the obsoletus Subzone Asciocythere, Schuleridea, Neocythere and Cytherelloidea dominated the faunas. Populations in southern England closely compare with the Paris Basin, showing only slight similarity with the Celtic Sea area to the west. With the opening of the seaway in the earliest Aptian, therefore, species migrating from the south-east appear to have been the most successful. Essentially similar ostracod associations during the late fissicostis Zone (obsoletus Subzone) and forbesi Zone indicate comparable environmental conditions throughout the Wessex Basin at that time.

Acknoledgements. Published with permission of the Executive Director of the British Geological Survey (NERC). 


\section{References}

Ainsworth, N.R. 1985 Upper Jurassic and Lower Cretaceous Ostracoda from the Fastnet Basin, offshore southwest Ireland. Irish Journal of Earth Sciences 7, 15-33.

Ainsworth N.R. 1986. Upper Jurassic and Lower Cretaceous Ostracoda from the Fastnet Basin, offshore southwest Ireland. Irish Journal of Earth Sciences 7, 145-168. Ainsworth, N.R., 1987. Upper Jurassic and Lower Cretaceous Ostracoda from the Fastnet Basin, offshore southwest Ireland. Irish Journal of Earth Sciences 8, 139-153. Ainsworth N.R., Horton, N.F. \& Penney, R.A. 1985. Lower Cretaceous micropalaeontology of the Fastnet Basin, offshore southwest Ireland. Marine Petroleum Geology 2, 341-349.

Ainsworth, N.R., O'Neill, M., Rutherford, M.M., Clayton, G., Horton, N.F. \& Penney, R.A. 1987. Biostratigraphy of the Lower Cretaceous, Jurassic and uppermost Triassic of the North Celtic Sea and Fastnet basins. In: Brooks, J. \& Glennie, K. (eds), Petroleum Geology of North West Europe, 611-622. [Graham \& Troutman].

Anderson, F.W. 1967. Ostracods from the Weald Clay of England. Bulletin of the Geological Survey of Great Britain No.27, 237-269.

Anderson, F.W. 1971. The sequence of ostracod faunas in the Wealden and Purbeck of the Warlingham borehole. In: Worssam, B. C. \& Ivimey-Cook, H. C. The stratigraphy of the Geological Survey borehole at Warlingham, Surrey. Bulletin of the Geological Survey of Great Britain No.36, Appendix B, 122-138.

Anderson, F.W. 1985. Ostracod faunas in the Purbeck and Wealden of England. Journal of Micropalaeontology 4, 1-68.

Babinot, J-F., Damotte, R., Donze, P., Grosdidier, E., Oertli, H.J. \& Scarenzi-Caroni, G. 1985 Crétacé infèrieur. In: Oertli, H.J. (ed.), Atlas des ostracodes de France (Paléozoic-Actuel). Bulletin des Centres de Recherches Exploration-Production ElfAquitaine, Mémoires 9, 163-209.

Bristow, C.R., Morter, A.A. \& Wilkinson, I.P. 1987. The stratigraphy and palaeontology of the Lower Greensand of the Hoes Farm Borehole, near Petworth, Sussex. Proceedings of the Geologists' Association 98, 217-227. 
Butler, G.W. 1922. On the Perna Bed and the Weald Clay at Reigate. Proceedings of the Geologists' Association 33, 313-318.

Casey, R. 1961. The stratigraphical palaeontology of the Lower Greensand. Palaeontology 3, 487-621.

Colin, J.-P., Lehmann, R.A. \& Morgan, B.E. 1981.Cretaceous and Late Jurassic biostratigraphyof the North Celtic Sea Basin, offshore southern Ireland. In: Neale, J.W. \& Brasier, M.D. (eds) Microfossils from Recent and fossil shelf seas. 122-155. [Ellis Horwood, Chichester].

Damotte R. \& Grosdider, E. 1963. Quelques ostracodes du Crétacé infèrieur de la Champagne Humide. 2: Aptien. Revue de Micropaléontologie 6, 153-168.

Damotte, R. 1971. Contribution à l'étude des Ostracodes marins dans le Crétacé du Bassin de Paris. Memoire de la Société géologiques de la France 50, 152pp.

Damotte R. \& Magniez-Janin, F. 1973. Ostracodes et foraminifères de l'Aptien infèrieur du Sondage du Bois du Perchois (Aube). Bulletin d' Information des Géologues du Bassin de Paris 36, 3-47.

Deroo, G. 1956. Etude critique au sujet des Ostracodes marins du Crétacé inférieur et moyen de la Champagne Humide et du Boulonnais. Revue de l' Institut français du Pétrole 11, 1499-1545.

Dingwall, R.G. \& Lott, G.K 1979. IGS Boreholes drilled from MV Whitehorn in the English Channel 1973-75. Reptort of the Institute of Geological Sciences 79/5, 45pp.

Fitton, W.H. 1847. A stratigraphical account of the section from Atherfield to Rocken End, on the south-west coast of the Isle of Wight. Quaterly Journal of the Geological Society of London 3, 289-327.

Haq, B.U., Hardenbol, J. \& Vail, P.R. 1987. Chronology of fluctuating sea levels since the Triassic. Science 235, 1156-1167.

Hart, M.B., Rajshekhar, C., Fitzpatrick, M., Milton, J.A. \& Wadsworth, A.J. 1991. The early Aptian transgression event in the United Kingdom. Historical Biology 5, 309-319. 
Heselbo S.P., Coe, A.L. \& Jenkyns, H.C. 1990. Recognition and documentation of depositional sequences from outcrop: an example from the Aptian and Albian on the eastern margin of the Wessex Basin. Journal of the Geological Society, London 147, 549-559.

Horne, D.J. 1995. A revised ostracod biostratigraphy for the Purbeck-Wealden of England. Cretaceous Research 16, 639-663.

Insole, A., Daley, B. \& Gale, A. 1998. The Isle of Wight. Geologists’ Association Guide no. 60, 132pp.

Kaye P. 1965. Ostracoda from the Aptian of the Isle of Wight, England. Paläontologische Zeitschrift 39, 33-50.

Kerth, M. \& Hailwood, E.A. 1988. Magnetostratigraphy of the Lower Cretaceous Vectis Formation (Wealden Group) on the Isle of Wight, southern England. Journal of the Geological Society, London 145, 351-360.

Lott , G.K., Ball, K C. \& Wilkinson, 1.P. 1985. Mid-Cretaceous stratigraphy of a cored borehole in the western part of the Central North Sea Basin. Proceedings of the Yorkshire Geological Society 45, 235-248.

Oertli, H.J. 1958. Ostracodes du Jurrasique supérieur du Bassin de Paris (SondageVernon 1). Revue de l' Institut Français du Pétrole 12, 647-695.

Ruffel, A. H. 1988. Palaeoecology and event stratigraphy of the Wealden-Lower Greensand transition in the Isle of Wight. Proceedings of the Geologists ' Association 99, 133-140.

Sauvagnat, J. 1999. Les Ostradcodes aptiens et albiens du Jura. Publications du Déparement de Géologie et Paléontologie, Université de Genève 24, 264pp.

Sauvagnat, J., Clavel, B., Charollais, J.\& Schroeder, R. 2001. Ostracodes barrémoaptiens de quelques vires marneuses de l'Urgonien Jurassien, Pré-Subalpin et Subalpin SE de France)- inventaire préliminaire et systématique. Archives de Science, Genève 54, 83-98.

Simpson, M.I. 1985. The stratigraphy of the Atherfield Clay Formation (Lower Aptian; Lower Cretaceous) at the type and other localities in southern England. Proceedings of the Geologists' Association 96, 23-45. 
Stewart, D.J., Ruffell, A.H., Wach, G.D. \& Goldring, R. 1991. Lagoonal sedimentation and fluctuating salinities in the Vectis Formation (Wealden Group, Lower Cretaceous) of the Isle of Wight, southern England. Sedimentary Geology 72, 117-134.

Thurrell, R.G., Worssam, B.C. \&Edmonds, E.A. 1968. Geology of the country around Haslemere. Explanation of sheet 301. Memoir of the Geological Survey of Great Britain.

Whatley, R.C. 1990. Ostracoda and global events. In: Whatley, R.C. \& Maybury, C. (eds) Ostracoda \& Global events, 3-24 [Chapman \& Hall].

Wilkinson, I.P. 1996. Palaeoenvironmental controls on British Ostracoda between 112.5 and $108 \mathrm{Ma}$ (Aptian). 21-28. In: Keen, M.C. (Ed.) Proceedings of the 2nd European Ostracodologists meeting, University of Glasgow, Scotland, 23rd-27th July 1993.

Young, B. \& Lake, R.D. 1988. Geology of the country around Brighton and Worthing. Memoir for the 1:50,000 geological sheets 318 and 333 (England and Wales) 


\section{Plate Caption}

Ostracoda from the Perna Member (Atherfield Clay Formation) of Sandown Bay, Isle of Wight. All material is housed in the palaeontological collections of the BGS, Keyworth, UK. Bar: $100 \mu \mathrm{m}$

1. Neocythere (Centerocythere) bordeti, left valve lateral view; from $0.2 \mathrm{~m}$ above base of the Perna Member (Atherfield Clay Formation).

2. Neocythere (Centrocythere) gottisi, left valve lateral view: from $0.2 \mathrm{~m}$ above base of the Perna Member (Atherfield Clay Formation).

3. Eocytheropteron stchepinskyi, carapace, right valve lateral view; from $0.2 \mathrm{~m}$ above base of the Perna Member (Atherfield Clay Formation).

4. Asciocythere albae albae, left valve lateral view; from $0.7 \mathrm{~m}$ above base of the Perna Member (Atherfield Clay Formation).

5. Asciopcythere albae albae, right valve lateral view; from $0.7 \mathrm{~m}$ above base of the Perna Member (Atherfield Clay Formation).

6. Schuleridea sulcata, right valve lateral view; from $0.2 \mathrm{~m}$ above base of the Perna Member (Atherfield Clay Formation).

7. Cythereis (Rehacythereis) geometrica, left valve lateral view; from $0.2 \mathrm{~m}$ above base of the Perna Member (Atherfield Clay Formation).

8. Platycythereis sp 1, right valve lateral view; from $0.2 \mathrm{~m}$ above base of the Perna Member (Atherfield Clay Formation).

9. Schuleridea sulcata, left valve lateral view; from $0.7 \mathrm{~m}$ above base of the Perna Member (Atherfield Clay Formation).

10. Cythereis cf buechlerae, right valve lateral view; from $0.2 \mathrm{~m}$ above base of the Perna Member (Atherfield Clay Formation).

11. "Protocythere" sp 3 of Babinot et al, 1985, right valve lateral view; from $0.7 \mathrm{~m}$ above base of the Perna Member (Atherfield Clay Formation).

12. Cythereis cf lamplughi, left valve lateral view; from $1.2 \mathrm{~m}$ above base of the Perna Member (Atherfield Clay Formation).

13.Protocythere derooi carapace, left valve lateral view; from $0.7 \mathrm{~m}$ above base of the Perna Member (Atherfield Clay Formation).

14.Protocythere croutesensis, left valve lateral view; from $0.2 \mathrm{~m}$ above base of the Perna Member (Atherfield Clay Formation).

15. Cytherelloidea sp nov., left valve lateral view; from $0.2 \mathrm{~m}$ above base of the Perna Member (Atherfield Clay Formation). 


\section{Figure Captions}

Fig. 1. Sketch map of the Wessex Basin to show localities discussed in the text.

Fig. 2. Early Aptian stratigraphy in the Wessex Basin together with the ranges of selected, biostratigraphically useful species. (D.d. Deshayesites deshayesi Zone; ABB Atherfield Bone Bed)

Fig. 3. Distribution of ostracoda in the earliest Aptian at Atherfield, Isle of Wight. For lithological key, see Fig. 6.

Fig. 4. Distribution of ostracoda in the earliest Aptian at Sandown, Isle of Wight. For lithological key, see Fig. 6.

Fig. 5. Distribution of ostracoda in the Atherfield Clay Formation in BGS borehole 75/35. For lithological key, see Fig. 6.

Fig. 6. Distribution of ostracoda in the Atherfield Clay Formation in Paylins Copse Borehole, Sussex.

Fig. 7. Distribution of ostracoda in the Atherfield Clay Formation in Pound Common Borehole, Sussex. For lithological key, see Fig. 6.

Fig. 8. Distribution of ostracoda in the Atherfield Clay Formation in Frog Farm Borehole, Sussex. For lithological key, see Fig. 6.

Fig. 9. Distribution of ostracoda in the Atherfield Clay and basal Hythe formations in Hoes Farm Borehole, Sussex. For lithological key, see Fig. 6.

Fig. 10. Suggested relationship between ostracod genera and salinity in the early Aptian of the Wessex Basin. 


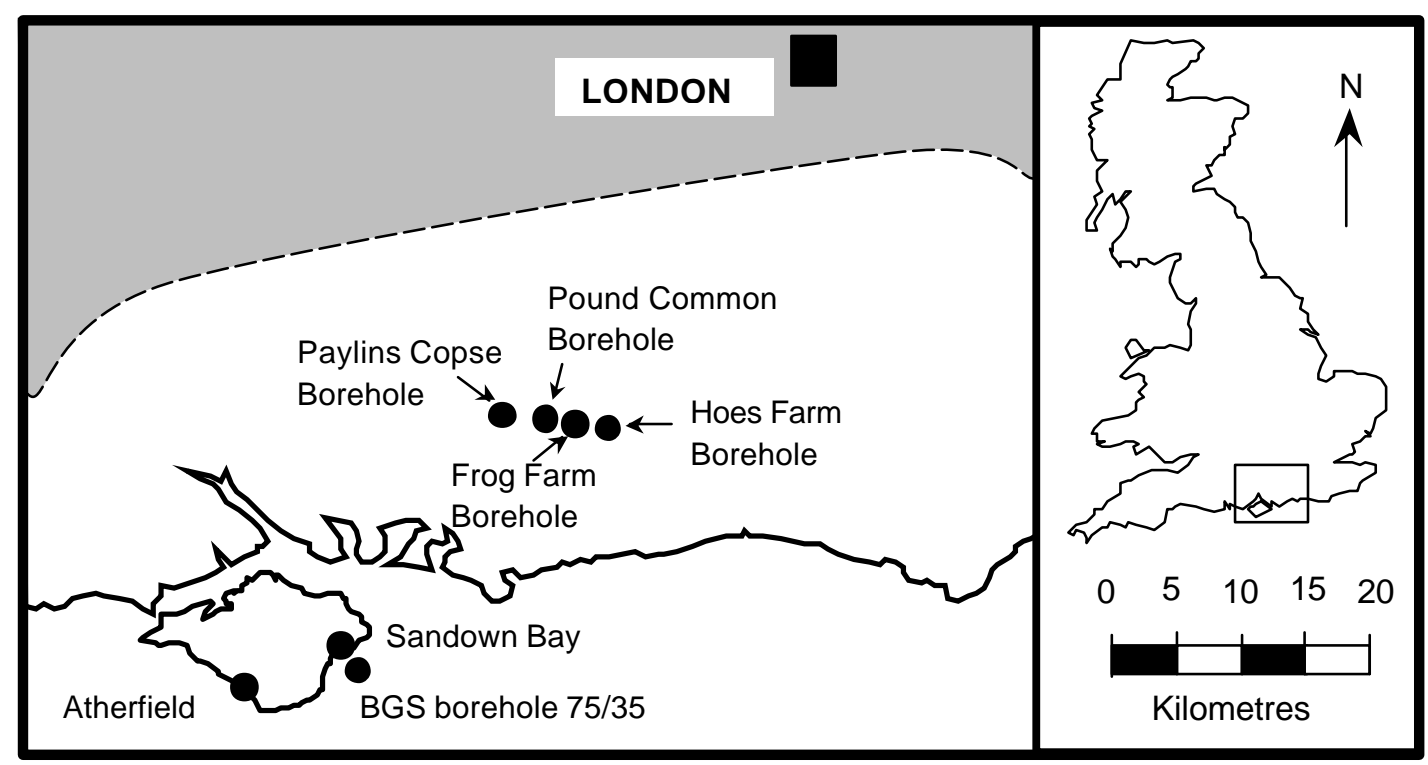




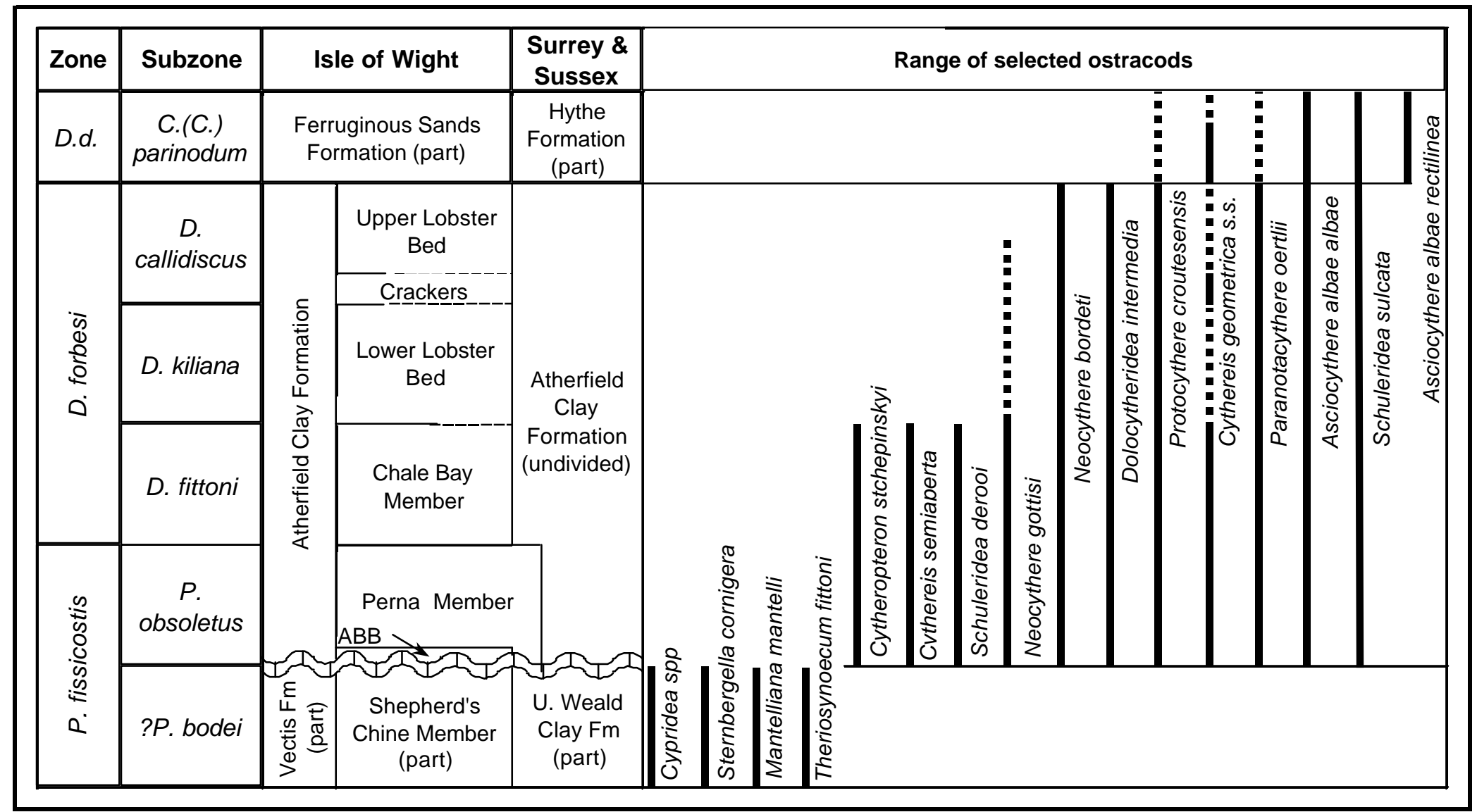




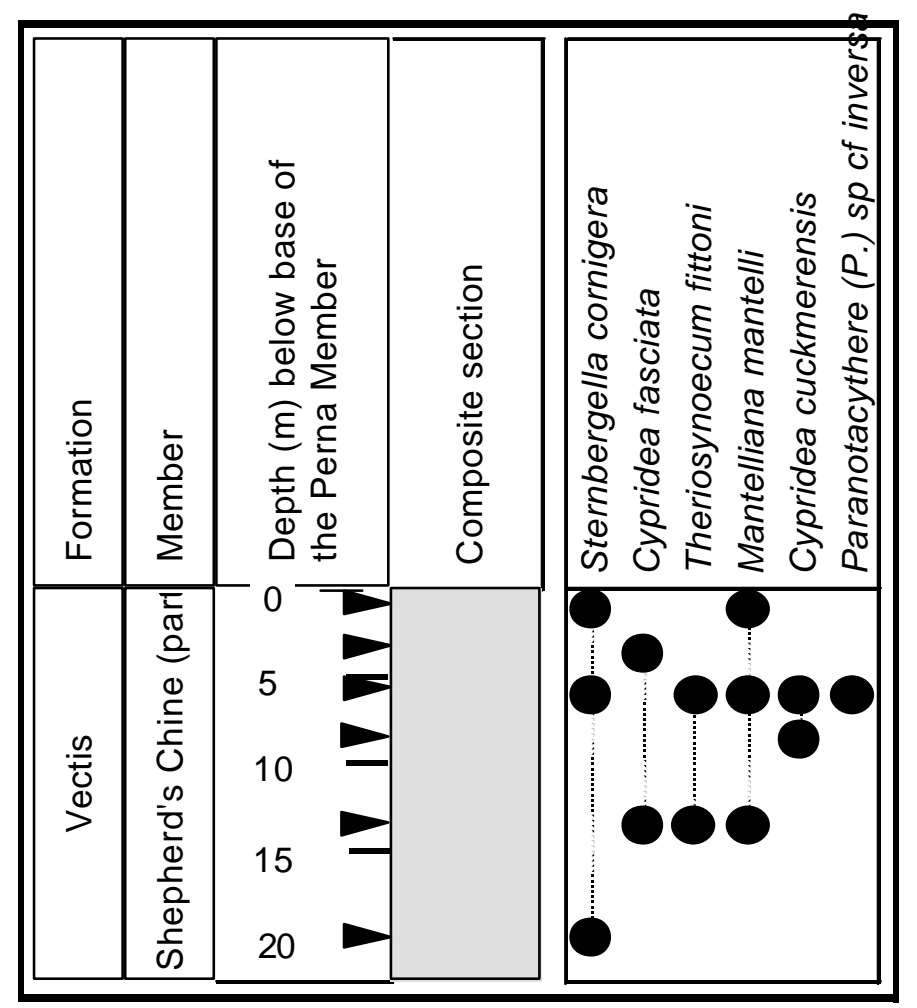




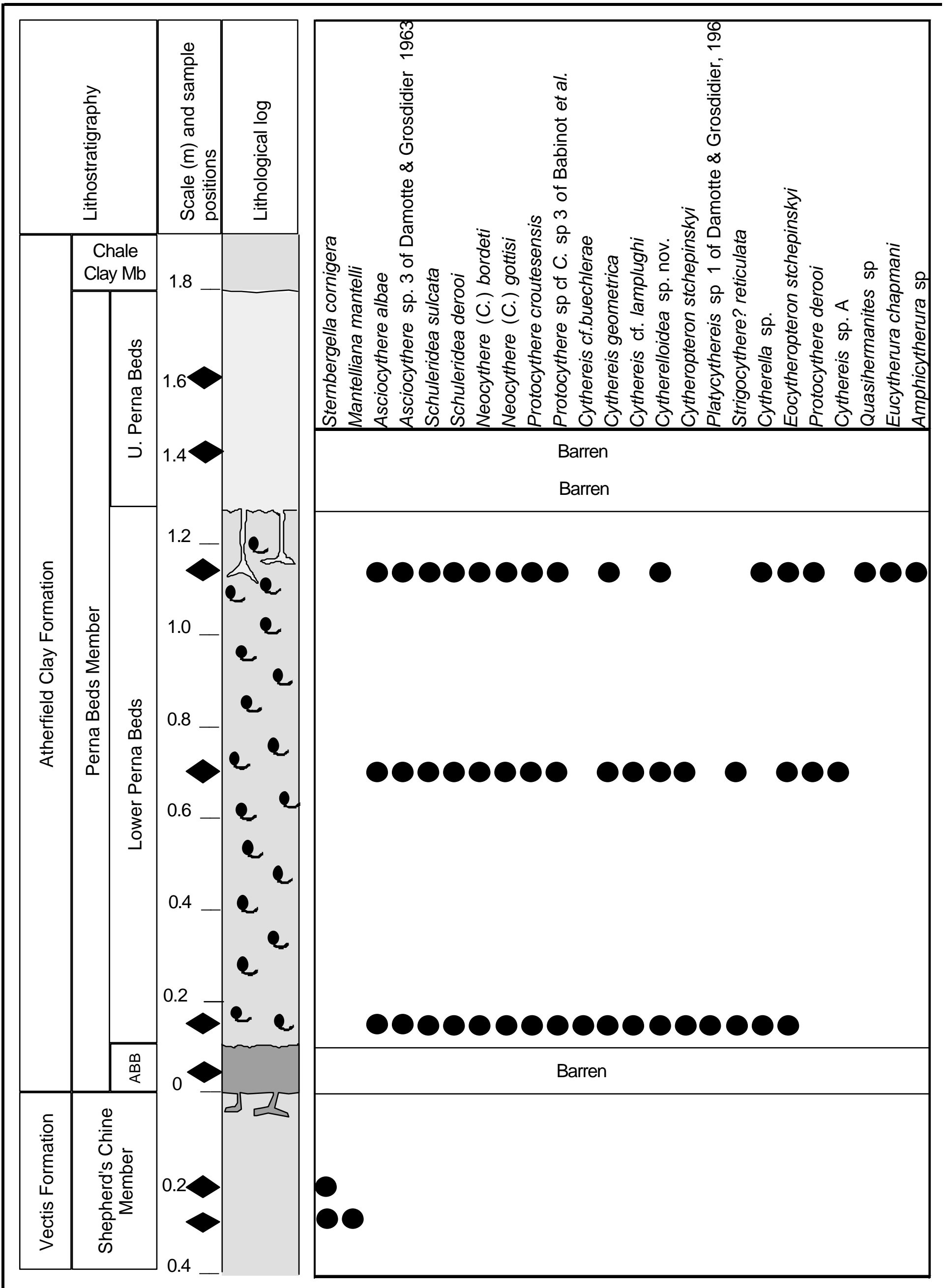




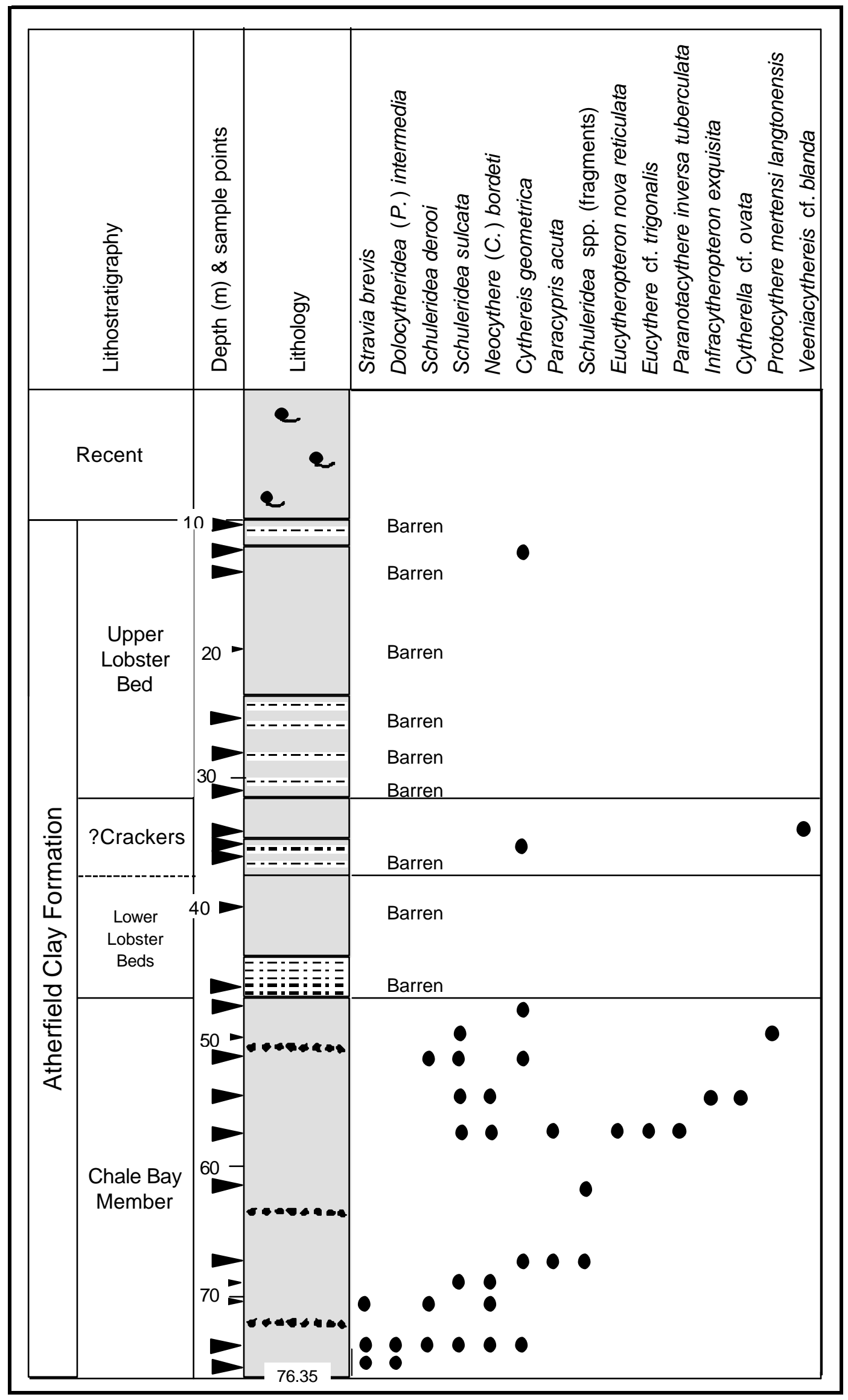




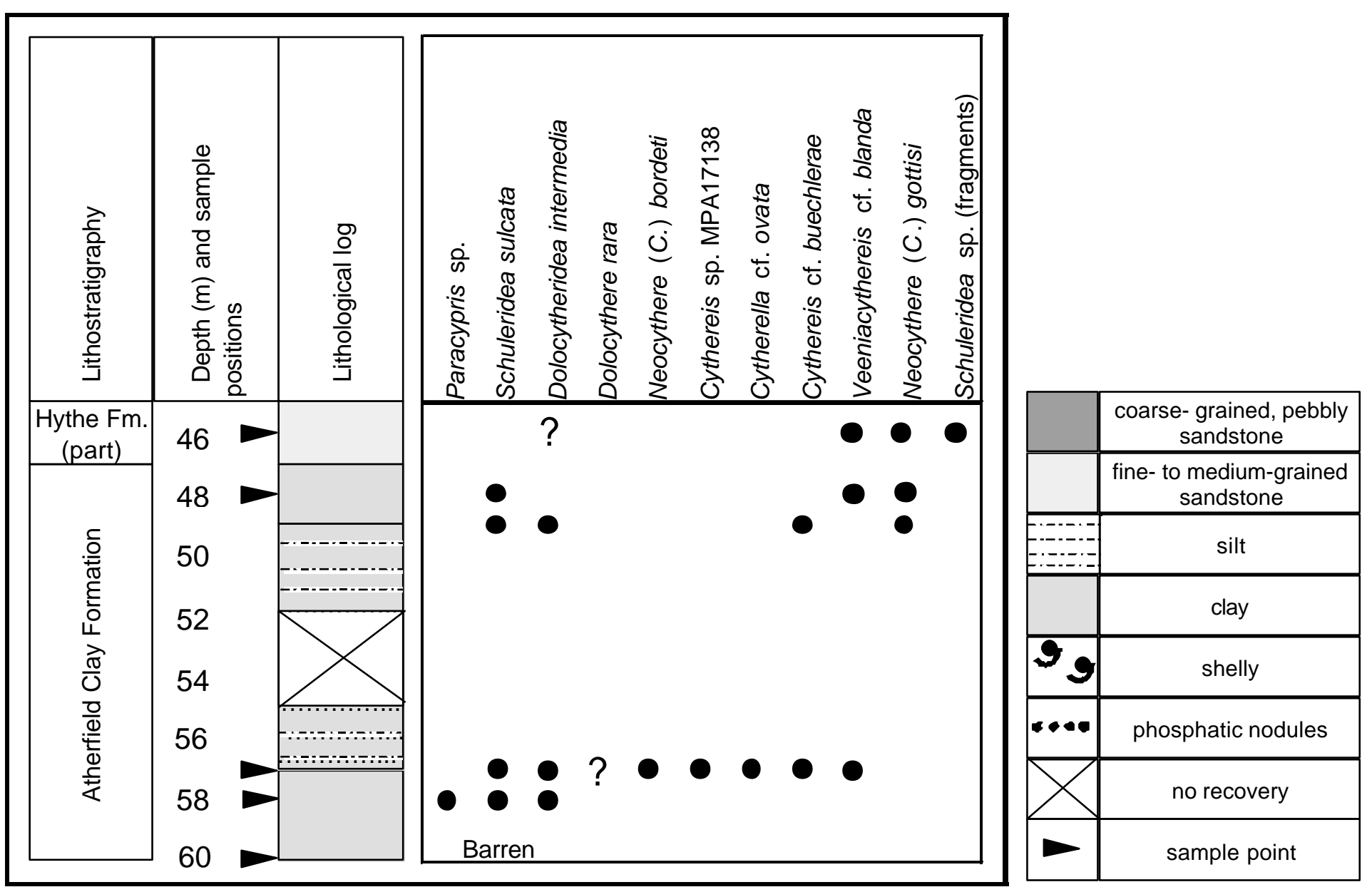




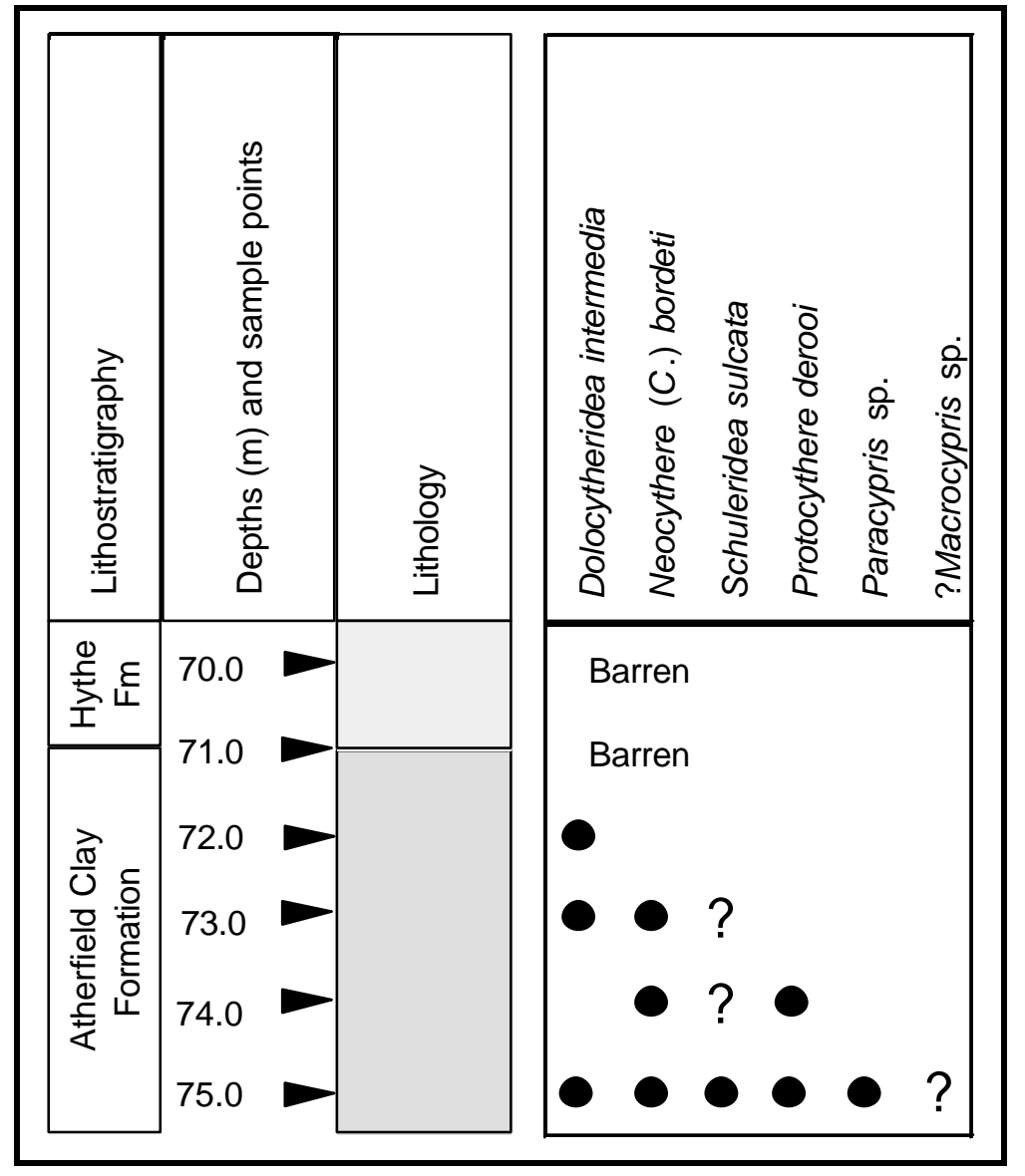




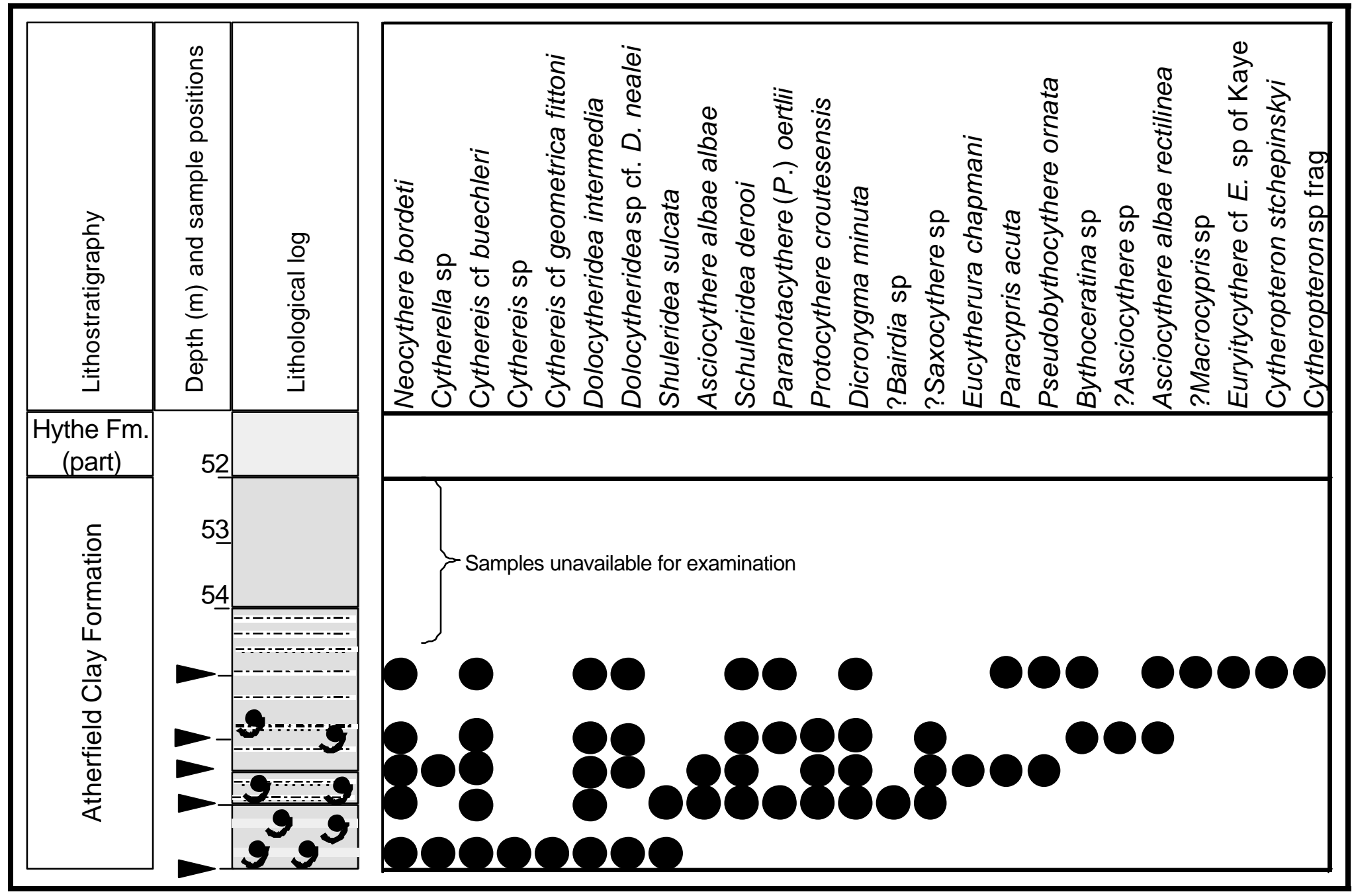




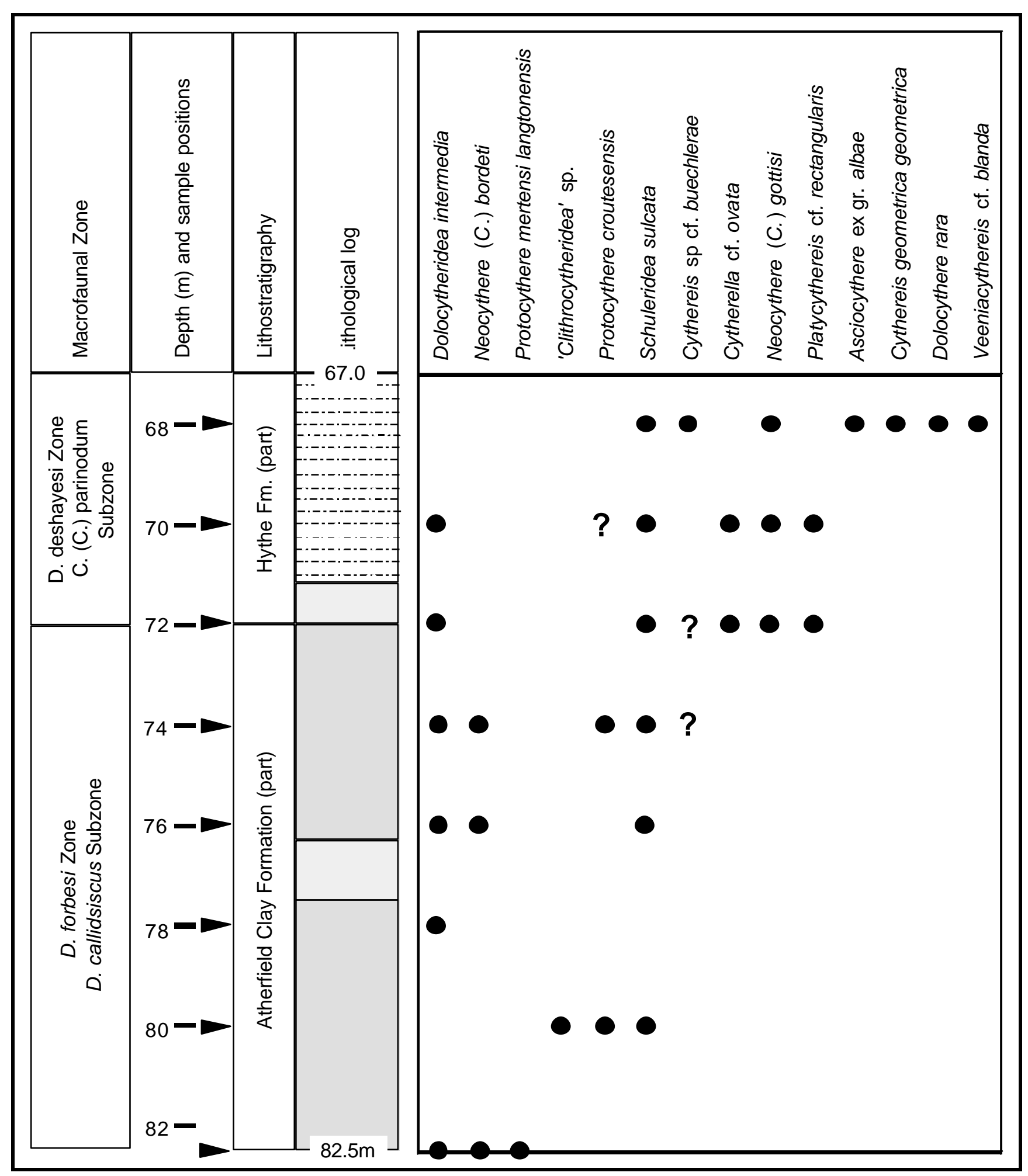




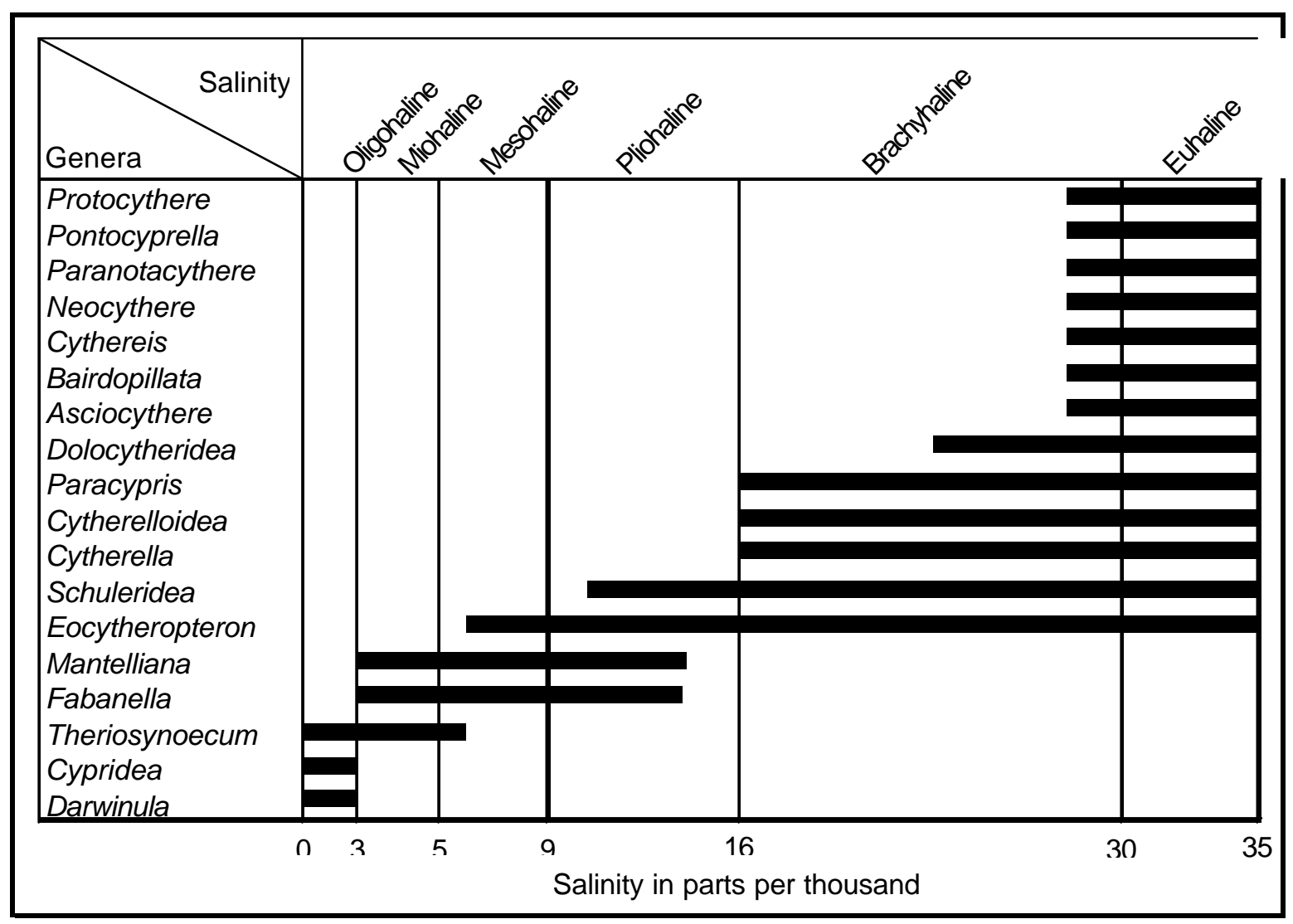




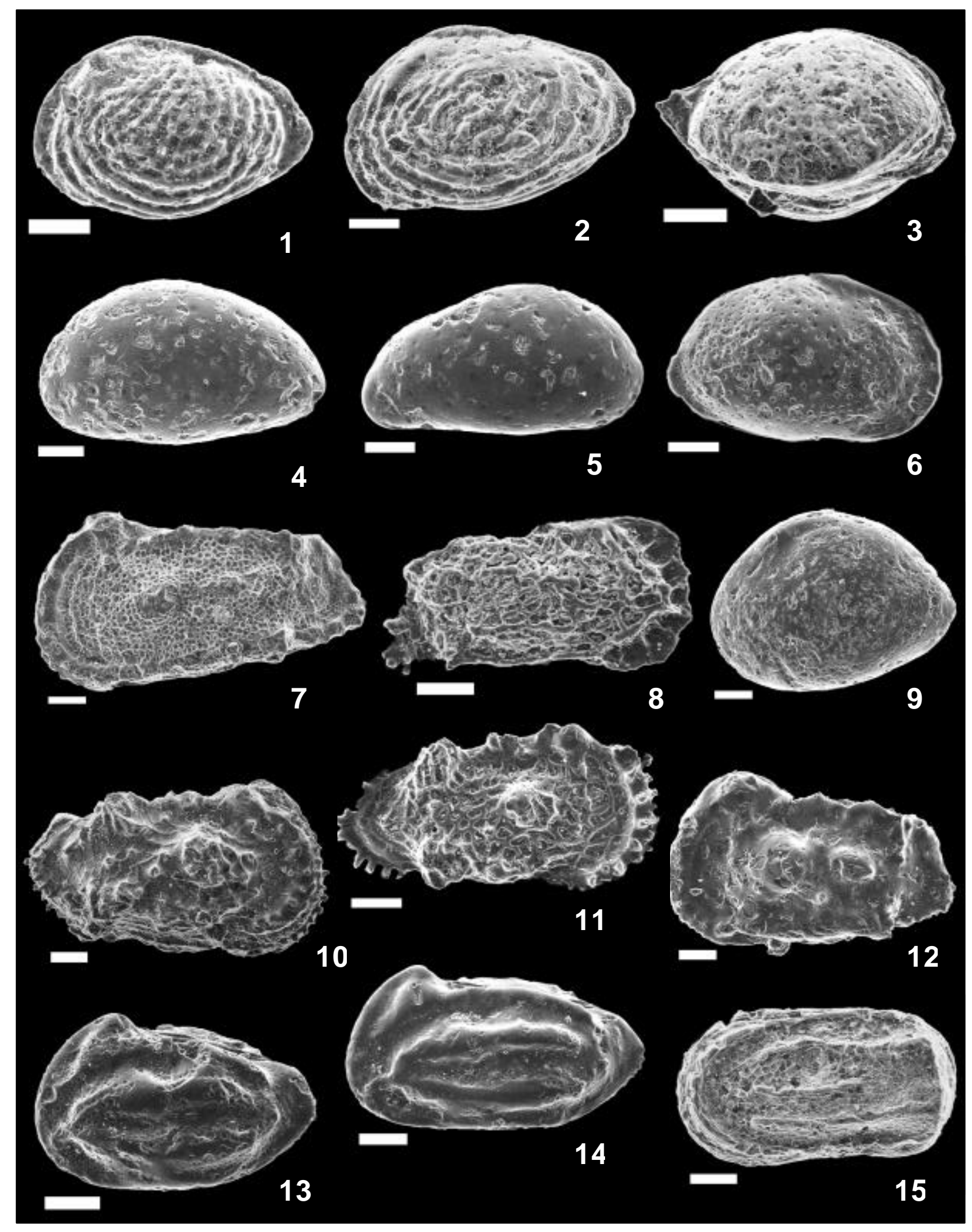

